\title{
PENGEMBANGAN STRATEGI PADA AKTIVITAS RANTAI NILAI PANAS BUMI (Studi Pada PT Geo Dipa Energi (Persero))
}

\author{
Maharani Ayuningtyas ${ }^{1}$, Harianto $^{2}$, Arief Safari $^{3}$ \\ 1,2 Sekolah Pascasarjana, Sekolah Bisnis, Institut Pertanian Bogor \\ ${ }_{3}^{3}$ Program Pascasarjana, Magister Keuangan Syariah, Institut Teknologi dan Bisnis Ahmad Dahlan
}

\begin{abstract}
Indonesia's geothermal potential is the second largest in the world. But in fact, the magnitude of its geothermal potential has not been utilized optimally. With investments and risks that are quite high, and a relatively long period of time makes investors do not much invest in this energy sector. Especially with the presence of single buyer, in this case is PT PLN (Persero). The issue of power purchase agreement between developers and PT PLN (Persero) is still become the biggest obstacle to the development of geothermal power plant. This study aims to formulate an appropriate strategy priority used by PT Geo Dipa Energi (Persero) in producing the optimal cost of generating electricity based on Minister of Energy and Mineral Resources Regulation Number 50 of 2017 concerning Utilization of Renewable Energy Sources for Electricity Supply. Data collection uses judgment sampling techniques. External environmental analysis is carried out through PESTLE analysis, while internal environmental analysis is carried out through value chain analysis. TOWS analysis is conducted to provide an alternative strategies, that from choices of alternative strategies will be prioritized using AHP analysis. The results of the study produced the chosen strategy priority that is to conduct intensive coordination with PT PLN (Persero) in negotiations to develop a new prospect area.
\end{abstract}

Key Words: analytical hierarchy process, development strategy, geothermal, value chain. PESTLE Analysis, TOWS analysis

\section{PENDAHULUAN}

Saat ini ketergantungan terhadap energi fosil masih relatif tinggi, lebih dari $90 \%$ penggunaan energi nasional berasal dari sumber energi fosil. Menurut Dewan Energi Nasional (DEN) tahun 2017, dari total kebutuhan energi primer di Indonesia sebesar 194 juta setara ton minyak (Mtoe), 43,3\% dipasok oleh minyak bumi, $18 \%$ oleh gas bumi, dan $31 \%$ oleh batubara. Energi fosil merupakan energi yang tidak terbarukan, proses pembentukannya memerlukan waktu jutaan tahun, sedangkan cadangan di alam habis jauh lebih cepat daripada proses pembentukannya. Pemakaian energi fosil yang terus menerus mengakibatkan dampak negatif terhadap lingkungan dan kesehatan makhluk hidup dikarenakan bahan bakar fosil mengandung persentase karbon yang tinggi dan memberikan kontribusi terbesar bagi pemanasan global.

Besarnya konsumsi energi fosil menjadikan cadangan migas di Indonesia terus menipis sehingga pemerintah harus menggunakan dana APBN (Anggaran Pendapatan dan Belanja Negara) untuk 
membeli minyak dari luar negeri dalam memenuhi kebutuhan energi masyarakat (Setyaningsih, 2011). Impor BBM yang terus meningkat pada akhirnya akan menguras devisa negara, bahkan menjadi pemicu melemahnya nilai tukar rupiah terhadap mata uang Amerika Serikat.

Hasil penelitian Badan Geologi Kementerian ESDM pada tahun 2014, diidentifikasi bahwa cadangan terbukti minyak bumi Indonesia sebesar 3,6 miliar barrel dan dengan tingkat produksi saat ini, maka usianya sekitar 13 tahun. Cadangan terbukti gas bumi sebesar 100,3 TCF dan akan bertahan selama 34 tahun. Cadangan batubara sebesar 31,35 miliar ton dan apabila diasumsikan nilai produksi setiap tahunnya sekitar 435 juta ton, maka secara ekonomis dapat dimanfaatkan sampai 72 tahun yang akan datang. Usia cadangan tersebut diasumsikan apabila tidak ada penemuan cadangan baru.

Indonesia berada pada pertemuan tiga lempeng tektonik utama, yaitu lempeng tektonik Eurosia, Hindia-Australia, dan Pasifik. Sebagai akibatnya, Indonesia memiliki ancaman bahaya geologi yang tinggi, namun juga menjadi negara yang kaya akan keanekaragaman energi dan mineral. Selain sumber energi fosil, posisi Indonesia yang berada di sepanjang jalur sabuk gunung api (ring of fire) membuat Indonesia memiliki potensi panas bumi yang dapat dikembangkan sebagai energi alternatif (Ditjen EBTKE, 2017). Posisi strategis ini membuat sumber panas bumi Indonesia tergolong mempunyai entalpi (temperatur) tinggi (Wahyuningsih, 2005). Pengalaman dari lapanganlapangan panas bumi yang telah dikembangkan di dunia maupun di Indonesia, menunjukkan bahwa sistem panas bumi bertemperatur tinggi dan sedang sangat potensial bila diusahakan untuk pembangkit listrik (Saptadji, 2012).
Melihat kenyataan bahwa cadangan energi fosil ketersediaanya terbatas, maka Indonesia harus secepatnya mengambil langkah diversifikasi energi untuk mengoptimalisasi sumber energi altematif yang potensial. Oleh karena itu, potensi panas bumi sebagai energi baru terbarukan (EBT) yang ramah lingkungan merupakan solusi cerdas untuk memenuhi kebutuhan energi sekaligus langkah konservasi alam jangka panjang (Latifah dan Gusmayanti, 2012).

Energi panas bumi merupakan energi yang ramah lingkungan karena setelah energi panas dalam bentuk fluida panas bumi diubah menjadi energi listrik, fluida dikembalikan ke reservoir melalui sumur injeksi. Penginjeksian air ke dalam reservoir merupakan suatu keharusan untuk menjaga keseimbangan masa sehingga memperlambat penurunan tekanan reservoir. Hal tersebut menjadikan energi panas bumi sebagai energi yang berkelanjutan (sustainable energy) (Saptadji, 2012).

Menurut Badan Geologi Kementerian ESDM (2017), potensi panas bumi Indonesia merupakan nomor dua terbesar di dunia. Namun, kapasitas terpasang PLTP Indonesia merupakan nomor tiga terbesar di dunia. Dunia baru memanfaatkan 10,58\% (12,9 GW) dari keseluruhan potensi panas bumi yang ada $(122,7 \mathrm{GW})$. Saat ini masih banyak negara yang mengabaikan potensi panas bumi, termasuk Indonesia karena lebih fokus kepada eksplorasi minyak dan gas bumi. Hal ini disebabkan oleh biaya investasi awal dan biaya operasional panas bumi lebih mahal, sehingga harga energinya menjadi mahal dan tidak dapat bersaing dengan harga energi konvensional yang masih disubsidi (Mary et al, 2017). Menurut Fandari et al (2014), beragam kendala dan tantangan dihadapi dalam pengembangan panas bumi, baik 
dari sisi kebijakan dan regulasi, pengaturan institusi, isu koordinasi lintas sektor, otonomi daerah, sumber daya manusia, isu tata kelola, dan hal teknis seperti akurasi data, proses tender, perlibatan masyarakat dalam proses pembangunan, negosiasi harga, perijinan, dan lainnya.

Tabel 1

Potensi dan Kapasitas Terpasang Panas Bumi Dunia Tahun 2017

\begin{tabular}{|c|c|c|c|c|c|c|}
\hline \multirow{2}{*}{$\frac{\text { No }}{1}$} & \multirow{2}{*}{$\begin{array}{c}\text { Negara } \\
\text { Amerika Serikat }\end{array}$} & \multicolumn{2}{|c|}{$\begin{array}{l}\text { Potensi } \\
(\mathrm{MW})\end{array}$} & \multicolumn{2}{|c|}{$\begin{array}{c}\text { Kapasitas Terpasang } \\
(\mathrm{MW})\end{array}$} & \multirow{2}{*}{$\begin{array}{c}\text { Rasio } \\
11,89 \% \\
\end{array}$} \\
\hline & & 30.000 & $24,44 \%$ & 3.567 & $27,48 \%$ & \\
\hline 2 & Indonesia & 28.508 & $23,23 \%$ & 1.809 & $13,93 \%$ & $6,35 \%$ \\
\hline 3 & Jepang & 23.400 & $19,07 \%$ & 542 & $4,18 \%$ & $2,32 \%$ \\
\hline 4 & Kenya & 15.000 & $12,22 \%$ & 676 & $5,21 \%$ & $4,51 \%$ \\
\hline 5 & Islandia & 5.800 & $4,73 \%$ & 665 & $5,12 \%$ & $11,47 \%$ \\
\hline 6 & Meksiko & 4.600 & $3,75 \%$ & 926 & $7,13 \%$ & $20,13 \%$ \\
\hline 7 & Turki & 4.500 & $3,67 \%$ & 1.005 & $7,74 \%$ & $22,33 \%$ \\
\hline 8 & Filipina & 4.000 & $3,26 \%$ & 1.868 & $14,39 \%$ & $46,70 \%$ \\
\hline 9 & Selandia Baru & 3.650 & $2,97 \%$ & 980 & $7,55 \%$ & $26,85 \%$ \\
\hline \multirow[t]{2}{*}{10} & Italia & 3.270 & $2,66 \%$ & 944 & $7,27 \%$ & $28,87 \%$ \\
\hline & Jumlah & 122.728 & $100 \%$ & 12.982 & $100 \%$ & $10,58 \%$ \\
\hline
\end{tabular}

Sumber: Ditjen EBTKE KESDM (2017)

Dari potensi panas bumi tersebut jelas menggambarkan bahwa peluang bisnis di sektor panas bumi masih sangat besar. Namun kenyataannya, besarnya potensi panas bumi Indonesia belum dimanfaatkan secara optimal. Dengan investasi dan risiko yang cukup tinggi, serta jangka waktu yang terbilang lama membuat para penanam modal tidak banyak berinvestasi di sektor energi ini. Terlebih dengan adanya single buyer, dalam hal ini PT PLN (Persero). Masalah kesepakatan harga beli listrik antara pengembang dengan PT PLN (Persero) masih menjadi hambatan terbesar untuk pengembangan PLTP.

Pembelian tenaga listrik dari PLTP oleh PT PLN (Persero) saat ini dilakukan berdasarkan harga patokan tertinggi yang telah diatur dalam Permen ESDM No. 50 Tahun 2017 tentang Pemanfaatan Sumber
Energi Terbarukan Untuk Penyediaan Tenaga Listrik. Aturan tersebut menyatakan bahwa harga jual listrik panas bumi adalah sebesar harga biaya pokok penyediaan pembangkitan (BPP Pembangkitan) nasional. Dalam hal BPP pembangkitan di sistem ketenagalistrikan setempat di atas rata-rata BPP pembangkitan nasional, harga pembelian tenaga listrik dari PLTP paling tinggi adalah sebesar BPP pembangkitan di sistem ketenagalistrikan setempat. Di sisi lain, apabila BPP pembangkitan di sistem ketenagalistrikan sama atau di bawah rata-rata BPP pembangkitan nasional, harga pembelian tenaga listrik dari PLTP ditetapkan berdasarkan kesepakatan para pihak.

Sebagai BUMN yang mendapat penugasan dari pemerintah, PT Geo Dipa Energi (Persero) dituntut untuk mencapai 
target yang telah ditentukan oleh pemerintah dalam pengembangan panas bumi di Indonesia. Dimana dalam "Road Map Pengelolaan Energi Nasional" pemerintah menetapkan rencana peningkatan pemanfaatan energi panas bumi di Indonesia secara bertahap hingga 9.500 MWe pada tahun 2025, yaitu 5\% dari bauran energi tahun 2025 atau setara 167,5 juta barrel minyak. Selain itu, sebagai BUMN tentunya PT Geo Dipa Energi (Persero) juga dituntut untuk menghasilkan laba bagi Perseroan sehingga harus efektif dan efisien dalam melakukan proses bisnisnya.

Penetapan aturan tersebut membuat tantangan industri panas bumi bukan hanya sekedar mengenai ketersediaan sumber dayanya, tetapi bagaimana pengembang panas bumi dapat menciptakan biaya pokok penyediaan pembangkitan (BPP Pembangkitan) yang optimum. Untuk mencapai tujuan tersebut, diperlukan sebuah strategi agar PT Geo Dipa Energi (Persero) dapat melanjutkan ke tahapan pengembangan sebelum dilakukan spending investasi yang besar.

Ketika perusahaan menerapkan suatu strategi, seringkali perusahaan dihadapkan pada beberapa masalah sehingga diperlukan analisis rantai nilai untuk menentukan faktor-faktor yang bepengaruh dalam menghasilkan biaya yang optimum. Rantai nilai merupakan alat dasar untuk mendiagnosis keunggulan bersaing dan menemukan cara untuk menciptakan dan mempertahankannya. Rantai nilai menguraikan perusahaan menjadi aktivitas-aktivitas yang relevan secara strategis untuk memahami perilaku biaya dan sumber diferensiasi yang sudah ada dan yang potensial (Porter, 1985).

Berdasarkan latar belakang yang telah dibahas, maka rumusan masalah pada penelitian ini adalah sebagai berikut:
1. Bagaimana kondisi eksternal dan internal PT Geo Dipa Energi (Persero) yang dapat mempengaruhi terciptanya BPP pembangkitan yang optimum?

2. Bagaimana alternatif strategi yang dapat dilakukan PT Geo Dipa Energi (Persero) dalam menghasilkan BPP pembangkitan yang optimum?

3. Bagaimana prioritas strategi yang tepat digunakan oleh PT Geo Dipa Energi (Persero) dalam menghasilkan BPP pembangkitan yang optimum?

\section{TELAAH PUSTAKA \\ Panas Bumi}

Panas bumi merupakan sumber daya panas alami, hasil interaksi antara panas yang dipancarkan batuan panas (magma) dan air tanah yang berada di sekitarnya, dimana cairan yang terpanasi terperangkap di dalam batuan yang terletak di dekat permukaan sehingga secara ekonomis dapat dimanfaatkan (Armstead, 1983).

\section{Manajemen Strategi}

Manajemen strategi menurut David (2011) adalah suatu seni dan ilmu pengetahuan dalam memformulasi, mengimplementasi, dan mengevaluasi keputusan lintas fungsional yang membuat suatu organisasi mampu mencapai tujuannya.

\section{Rantai Nilai}

Analisis rantai nilai merupakan salah satu teknik untuk membantu menilai sumber daya organisasi dalam menentukan kekuatan dan kelemahan perusahaan. Setiap perusahaan merupakan kumpulan aktivitas yang dilakukan untuk mendesain, memproduksi, memasarkan, menyerahkan, dan mendukung produknya (Wheelen dan Hunger, 2012). 
Menurut Porter (1985), aktivitas rantai nilai dapat dibagi menjadi dua jenis, yaitu aktivitas utama dan aktivitas pendukung. Analisis rantai nilai adalah cara yang efektif untuk menguji interaksi di antara aktor-aktor rantai nilai dalam membantu mengidentifikasi sumber daya yang diperlukan untuk berhasil bersaing dan bagaimana masing-masing aktor rantai nilai dapat memaksimalkan nilai tambah dari rantai nilainya (Walters dan Rainbird, 2007).

\section{Analisis PESTLE}

Rastogi dan Trivedi (2016) menjelaskan analisis PESTLE (Political Economic Social Technology Legal Environment) adalah alat perencanaan strategis yang digunakan untuk mengevaluasi lingkungan eksternal dengan menganalisis faktor-faktor politik, ekonomi, sosial, teknologi, hukum, dan lingkungan yang mempengaruhi suatu organisasi.

\section{Analisis Tows (Threats, Opportunities, Weakness, Strength)}

Matriks TOWS dikembangkan oleh Weihrich (1982) sebagai satu langkah lebih jauh dari analisis SWOT yang membuatnya lebih dapat diterapkan dan didasarkan pada kenyataan. Matriks TOWS digunakan untuk menganalisis lingkungan eksternal (ancaman dan peluang) dan lingkungan internal (kelemahan dan kekuatan) untuk menggambar strategi dan visi kepada para pembuat keputusan di perusahaan. Setiap kombinasi faktor eksternal dan internal menghasilkan strategi baru dimana terdapat empat kombinasi berbeda yang dikembangkan (Ravanava dan Charantimath, 2012).

\section{Tabel 2} Matriks TOWS

\begin{tabular}{|c|c|c|}
\hline $\begin{array}{l}\text { EXTERNAL } \\
\text { FACTORS } \\
\end{array}$ & $\begin{array}{c}\text { STRENGTHS-S } \\
\text { Tentukan 5-10 faktor-faktor } \\
\text { kekuatan internal } \\
\text { perusahaan }\end{array}$ & $\begin{array}{c}\text { WEAKNESSES-W } \\
\text { Tentukan 5-10 faktor-faktor } \\
\text { kelemahan internal } \\
\text { perusahaan }\end{array}$ \\
\hline $\begin{array}{c}\text { OPPORTUNITIES-0 } \\
\text { Tentukan 5-10 faktor-faktor } \\
\text { peluang eksternal } \\
\text { perusahaan }\end{array}$ & $\begin{array}{c}\text { STRATEGI SO } \\
\text { Ciptakan strategi yang } \\
\text { menggunakan kekuatan } \\
\text { untuk memanfaatkan } \\
\text { peluang }\end{array}$ & $\begin{array}{c}\text { STRATEGI WO } \\
\text { Ciptakan strategi yang } \\
\text { meminimalkan kelemahan } \\
\text { untuk memanfaatkan } \\
\text { peluang }\end{array}$ \\
\hline $\begin{array}{c}\text { THREATS-T } \\
\text { Tentukan 5-10 faktor-faktor } \\
\text { ancaman eksternal } \\
\text { perusahaan }\end{array}$ & $\begin{array}{c}\text { STRATEGI ST } \\
\text { Ciptakan strategi yang } \\
\text { menggunakan kekuatan } \\
\text { untuk mengatasi ancaman }\end{array}$ & $\begin{array}{c}\text { STRATEGI WT } \\
\text { Ciptakan strategi yang } \\
\text { meminimalkan kelemahan } \\
\text { untuk mengatasi ancaman }\end{array}$ \\
\hline
\end{tabular}

Sumber: Weihrich (1982)

\section{Analytic Hierarchy Process (AHP)}

Menurut Marimin dan Maghfiroh (2011), terdapat 3 prinsip kerja AHP dalam memecahkan persoalan, yaitu:

a) Penyusunan Hierarki

Penyusunan hierarki dimulai dari permasalahan kompleks yang diuraikan menjadi elemen pokoknya, elemen pokok ini diuraikan lagi, dan seterusnya secara hierarki.

b) Penetapan Prioritas Untuk setiap level pada hirearki, perlu 
dilakukan perbandingan berpasangan (pairwise comparison) untuk menentukan prioritas. Menurut Saaty (1983), skala 1 sampai 9 adalah skala terbaik dalam mengekspresikan pendapat.

c) Konsistensi Logis

AHP mengukur konsistensi menyeluruh dari berbagai pertimbangan melalui suatu rasio konsistensi. Nilai rasio konsistensi harus $\leq 10 \%$, jika $>10 \%$ penilaiannya masih acak dan perlu diperbaiki.

\section{METODE PENELITIAN Waktu dan Tempat Penelitian}

Penelitian dilaksanakan pada PT Geo Dipa Energi (Persero) yang berlokasi di Aldevco Octagon Building, Jl. Warung Jati Barat No. 75, Jakarta Selatan. Pengumpulan data dilaksanakan pada bulan Maret hingga Desember 2018.

\section{Desain Penelitian}

Desain penelitian menggunakan metode deskriptif berdasarkan studi kasus terhadap rantai nilai di PT Geo Dipa Energi (Persero). Metode deskriptif merupakan suatu metode riset yang tujuannya menggambarkan karakteristik dari suatu objek. Salah satu pendekatan yang populer dari riset ini adalah pendekatan survei. Survei dapat dilakukan dengan teknik wawancara, obsevasi, dan kuesioner terhadap responden.

\section{Jenis dan Sumber Data Penelitian}

Jenis data yang dikumpulkan terdiri atas data primer dan data sekunder, baik yang bersifat kuantitatif maupun kualitatif. Data primer diperoleh melalui wawancara, observasi, dan kuesioner. Data sekunder diperoleh dari studi literatur, dokumen milik perusahaan, dan instansi terkait (Kementerian ESDM, Kementerian LHK, dan SKK Migas).

\section{Teknis Analisis Data Penelitian}

Teknik analisis data yang mendasari penelitian ini menggunakan beberapa metode yang dapat dilihat pada Tabel 3 .

Tabel 3

Teknik Analisis Data

\begin{tabular}{clll}
\hline No & \multicolumn{1}{c}{ Tujuan } & Alat Analisis & \multicolumn{1}{c}{ Output } \\
\hline 1 & $\begin{array}{l}\text { Analisis kondisi } \\
\text { eksternal perusahaan }\end{array}$ & Analisis & PESTLE \\
\hline 2 & $\begin{array}{l}\text { Analisis kondisi } \\
\text { internal perusahaan }\end{array}$ & $\begin{array}{l}\text { Analisis } \\
\text { Rantai Nilai }\end{array}$ & $\begin{array}{l}\text { Isu strategis eksternal yang mempengaruhi } \\
\text { PT Geo Dipa Energi (Persero) }\end{array}$ \\
\hline 3 & $\begin{array}{l}\text { Perumusan alternatif } \\
\text { strategi }\end{array}$ & Matriks TOWS & $\begin{array}{l}\text { Rumusan alternatif strategi yang dapat } \\
\text { dipilih oleh PT Geo Dipa Energi (Persero) }\end{array}$ \\
\hline 4 & $\begin{array}{l}\text { Perumusan prioritas } \\
\text { strategi }\end{array}$ & AHP & $\begin{array}{l}\text { Prioritas strategi yang relevan dengan } \\
\text { kondisi PT Geo Dipa Energi (Persero) }\end{array}$ \\
\hline
\end{tabular}

\section{Sampel Penelitian}

Pengambilan data menggunakan purposive sampling dengan teknik judgement sampling, yaitu dengan sengaja memilih responden berdasarkan pertimbangan bahwa responden memiliki keahlian mengenai subjek yang diteliti. Penelitian melibatkan 1 (satu) orang responden eksternal dan 7 (tujuh) orang responden internal yang dapat dilihat pada Tabel 4 . 
Tabel 4

Daftar Responden

\begin{tabular}{lll}
\hline Responden & \multicolumn{1}{c}{ Nama Responden } & \multicolumn{1}{c}{ Jabatan } \\
\hline \multirow{3}{*}{ Internal } & Aulijati Wachjudiningsih & Direktur Umum dan SDM PT Geo Dipa Energi \\
\cline { 2 - 3 } & M. Ikbal Nur & Direktur Keuangan PT Geo Dipa Energi \\
\cline { 2 - 3 } & Idham Purnama & Human Capital Manager PT Geo Dipa Energi \\
\cline { 2 - 3 } & Deri Yudiandri & Procurement Manager PT Geo Dipa Energi \\
\cline { 2 - 3 } & Muhammad Reza Iqbal & Management \& Operation Auditor PT Geo \\
& Dipa Energi \\
\cline { 2 - 3 } & Supremelehaq Taqwim & Business Development Assistant Manager \\
& & PT Geo Dipa Energi \\
\cline { 2 - 3 } & Erwin & Komite Audit Komisaris PT Geo Dipa Energi \\
\hline Eksternal & Carson Hakama Ritonga & Analis Pengawasan Eksplorasi dan Eksploitasi \\
& & Panas Bumi Dirjen EBTKE Kementerian ESDM \\
\hline
\end{tabular}

\section{Kerangka Penelitian}

Tahapan pertama yang dilakukan pada penelitian ini adalah menghimpun informasi mengenai kondisi umum PT Geo Dipa Energi (Persero) dan stakeholdernya, Tahapan selanjutnya adalah menganalisis dan mengkaji kondisi lingkungan eksternal dan internal perusahaan. Analisis lingkungan eksternal dilakukan melalui analisa faktor politik, ekonomi, sosial, teknologi, hukum, dan lingkungan (PESTLE) yang berpengaruh terhadap perusahaan, sedangkan analisis lingkungan internal dilakukan melalui aktivitas rantai nilai perusahaan.

Selanjutnya dilakukan analisis TOWS untuk memberikan beberapa alternatif strategi yang dapat dipilih oleh perusahaan dengan mempertimbangkan faktor ekstenal perusahaan yang terdiri dari peluang dan ancaman, serta faktor internal perusahaan yang terdiri dari kekuatan dan kelemahan. Setelah didapatkan beberapa pilihan alternatif strategi, maka dilakukan pemilihan prioritas alternatif strategi menggunakan Analytical Hirearchy Process (AHP) dengan melibatkan pandangan para ahli yang terkait dengan industri panas bumi.
Dari hasil penilaian tersebut, nantinya dapat diketahui rekomendasi alternatif strategi yang menjadi prioritas utama perusahaan dan dilanjutkan dengan implikasi manajerial. Kerangka penelitian ini dapat dilihat pada Gambar 1.

\section{HASIL DAN PEMBAHASAN}

Secara ekonomi, bisnis pembangkit listrik tenaga panas bumi lebih menyerupai industri minyak atau gas dibandingkan dengan bisnis energi terbarukan lainnya. Hal tersebut karena sumber daya panas bumi perlu ditemukan, dibor, dan kemudian diekstrak. Seperti halnya sumber daya minyak dan gas bumi, energi panas bumi merupakan sumber daya yang juga memerlukan eksplorasi. Perbedaannya adalah setelah sumber minyak atau gas ditemukan, dapat langsung diproduksi dan kemudian dijual. Namun untuk sumber daya panas bumi, bahkan setelah penemuan dan pengeboran, sumber panas bumi tidak segera mampu menghasilkan laba atas investasi sampai selesai dibangun pembangkit listrik yang cocok dan tersambung ke jaringan listrik. Dengan demikian, ada penundaan yang signifikan 
sebelum pendapatan apapun dapat direalisasikan (SMI Insight, 2015).

Karakteristik pengusahaan energi panas bumi merupakan kegiatan yang padat modal dan padat teknologi dengan risiko tinggi. Tetapi hal ini akan memiliki arti besar bagi Indonesia jika dilihat dari perspektif jangka panjang. Sifat sumber daya panas bumi yang berumur panjang dan melimpah, serta tidak bisa diekspor menjadi sangat berarti bagi kepentingan negara jika dimanfaatkan secara maksimal. Hal ini akan membantu diversifikasi baruan enegi, meningkatkan keamanan energi, dan mengoptimalkan nilai ekspor komoditas energi yang dapat digantikan oleh batu bara, minyak, dan gas. Panas bumi merupakan energi baru terbarukan yang sangat handal, dapat diprediksi dalam hal harga, serta ramah lingkungan sehingga sumber energi panas bumi sangat baik untuk memenuhi kebutuhan energi Indonesia (Darma et al, 2010).

Gambar 1

\section{Kerangka Penelitian}

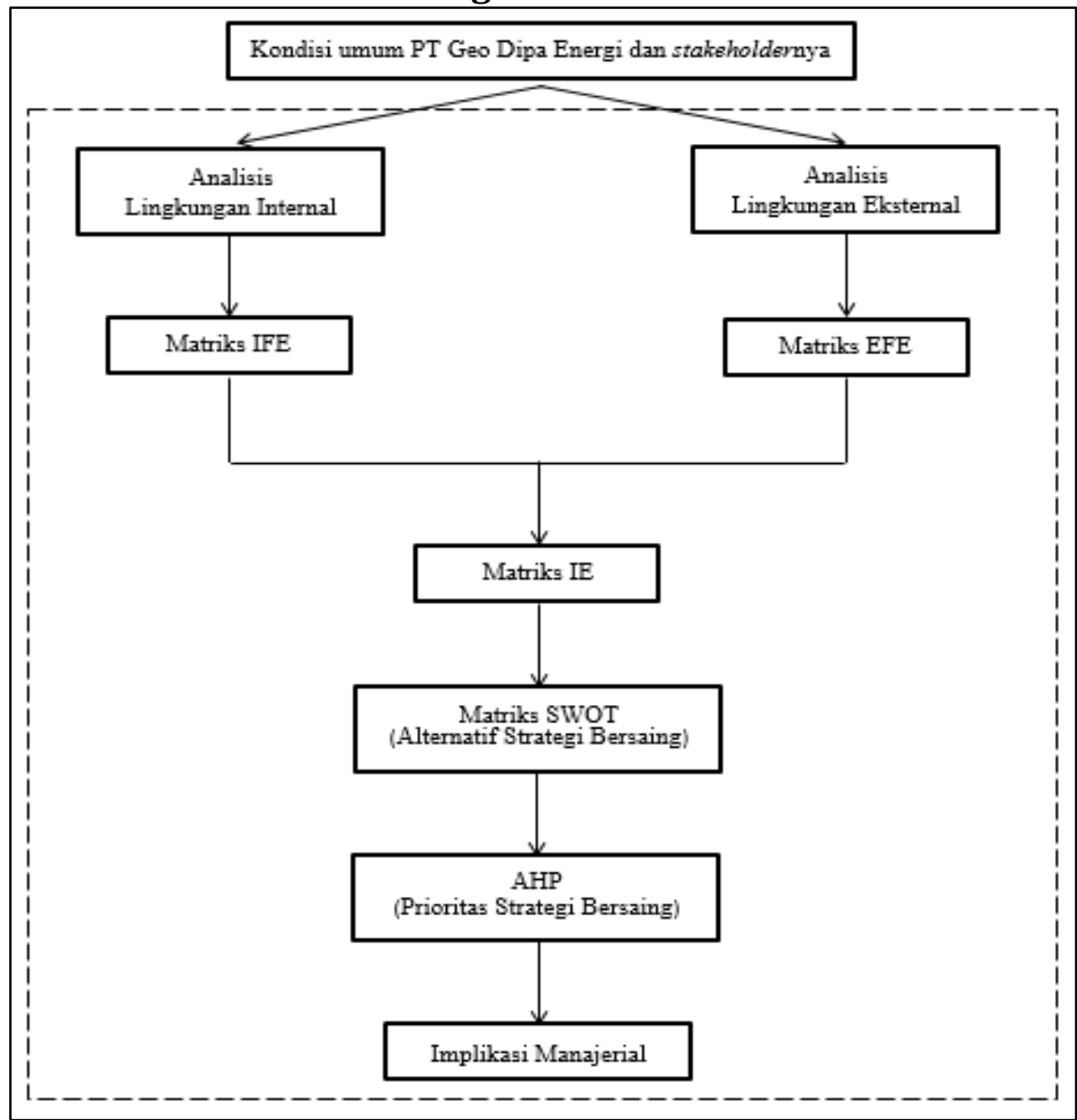

Keterangan: Batas penelitian Alur proses 


\section{Kondisi Eksternal Perusahaan}

Lingkungan eksternal yang mempengaruhi aktivitas perusahaan ditelusuri dari 6 (enam) aspek, yaitu politik, ekonomi, sosial, teknologi, hukum, dan lingkungan:

1. Politik

Dengan begitu banyak kepentingan dan unsur politis yang kental, upaya penggunaan energi baru terbarukan dirasa belum sempurna. Pada kenyataannya beberapa proyek panas bumi ada yang bermasalah, bahkan terlihat adanya aksi saling sikut antar kepentingan politik. Faktor yang menghambat pengembangan panas bumi yakni kerap adanya penolakan dari masyarakat, dimana ada kepentingan politik dibalik penolakan tersebut. Contoh nyatanya saat berlangsung pemilihan kepala darerah (pilkada). Ketika salah satu calon mendukung pengembangan panas bumi sedangkan calon lawannya menolak, seketika itu akan muncul informasiinformasi negatif mengenai panas bumi. Bahkan beredar isu-isu tidak masuk akal seperti isu penjualan gunung kepada pihak asing. Perilaku calon kepala daerah tersebut membuat masyarakat mendapatkan informasi yang tidak benar mengenai pengembangan panas bumi dan pada akhirnya anggapan negatif itu mengendap dan mengakar pada masyarakat sekitar yang daerahnya kaya akan sumber energi panas bumi.

2. Ekonomi

Dalam rangka mendukung kegiatan penyediaan eksplorasi panas bumi sebagai sumber energi baru terbarukan, pemerintah merumuskan konsep mengenai pengelolaan dana Pembiayaan Infrastruktur Sektor Panas Bumi (PISP). Pengelolaan dana PISP dilaksanakan oleh PT Sarana Multi Infrastruktur (SMI) sebagai BUMN di bawah Kementerian Keuangan. Dana PISP bersumber dari APBN dan hibah Bank Dunia yang bekerja sama dengan climate funds, mempersiapkan Geothermal Resource Risk Mitigation Project (GREM) dengan tujuan penyertaan modal dan memfasilitasi pemberian pinjaman kepada pengembang dalam bidang kelistrikan berbasis tenaga panas bumi melalui blended soft loan. Fokus dari pengembangan proyek ini adalah untuk meningkatkan investasi dalam pengembangan energi panas bumi dan mengurangi emisi gas rumah kaca di Indonesia.

Berdasarkan Permen Keuangan (PMK) No. 62 Tahun 2017 tentang Pengelolaan Dana Pembiayaan Infrastruktur Sektor Panas Bumi pada Perusahaan Perseroan PT SMI, dana PISP dapat digunakan untuk pemberian pinjaman, penyertaan modal (hibah), dan/atau penyediaan data dan informasi panas bumi atas kegiatan eksplorasi panas bumi. Atas pertimbangan Kementerian Keuangan, dana PISP dapat diberikan kepada entitas publik seperti BUMN atau anak perusahaan BUMN dengan skema risk sharing, yaitu pengampunan hingga 50\% jika eksplorasi dianggap tidak berhasil dan jika eksplorasi dinilai berhasil, peminjam harus membayar seluruh pinjaman termasuk biaya bunga dan imbalan keberhasilan. Imbalan keberhasilan ini dirancang untuk menutupi biaya pengelolaan dan pengoperasian dana oleh PT SMI.

Mengenai penggunaan konten lokal atau Tingkat Kandungan Dalam Negeri (TKDN) di sektor pembangkit panas bumi, jumlahnya masih tergolong kecil dikarenakan masih jarang yang diproduksi di dalam negeri. Terkait dengan hal tersebut, pemerintah membuat kebijakan dalam Permen Keuangan (PMK) No. 142 Tahun 2015 tentang Perlakuan Pajak Pertambahan Nilai dan Pajak Penjualan Barang Mewah Atas Impor Barang Kena Pajak yang Dibebaskan dari Pungutan Bea Masuk. Dalam pasal 2 ayat 3 peraturan tersebut, dinyatakan bahwa impor barang kena pajak yang digunakan untuk kegiatan 
eksplorasi dan eksploitasi panas bumi dapat dibebaskan bea masuk (BM), pungutan pajak pertambahan nilai (PPN), maupun pajak penjualan atas barang mewah (PPnBM). Namun pada prakteknya, persentase TKDN paling sedikit yang digunakan dalam industri panas bumi ada pada tahapan pemanfaatan (impor turbin), tetapi jenis barang ini tidak dimasukkan dalam aturan tersebut. Diperlukan revisi dengan memasukkan jenis barang keperluan tahapan pemanfaatan panas bumi agar dapat memberikan kepastian usaha bagi keberlanjutan pengembangan panas bumi.

3. Sosial

Dalam mengembangkan panas bumi, penting untuk menerapkan prinsip kehatihatian serta menjaga dan membangun nilai kearifan lokal masyarakat sekitar dengan mempertimbangkan aspek sosial. Pemahaman masyarakat yang berbedabeda mengenai panas bumi memerlukan komunikasi dan sosialisasi secara bertahap mengenai manfaat panas bumi bagi kehidupan masyarakat sekitar.

Pemerintah mewajibkan pengembang panas bumi untuk memberikan bonus produksi kepada pemerintah daerah melalui UU No. 21 Tahun 2014 pasal 53 tentang Panas Bumi. Bonus produksi merupakan salah satu bentuk pemanfaatan pengembangan panas bumi yang bertujuan untuk dapat dirasakan langsung oleh daerah penghasil. Penggunaan bonus produksi ini diprioritaskan untuk masyarakat yang berada paling dekat kegiatan pengusahaan panas bumi. Peraturan ini akan memberikan jaminan hukum bagi daerah penghasil supaya dapat lebih merasakan manfaat dari kegiatan pengusahaan panas bumi. Selain itu, dengan peraturan ini diharapkan dapat memberikan manfaat sebesar-besarnya bagi masyarakat sekitar sehingga akan meningkatkan taraf hidup masyarakat lokal, sekaligus dapat memupuk rasa kepemilikan masyarakat terhadap kegiatan pengusahaan panas bumi sehingga tercipta sinergi antara masyarakat dengan badan usaha pengembang panas bumi.

4. Teknologi

Sistem panas bumi di Indonesia pada umumnya merupakan sistem hidrothermal yang mempunyai temperatur tinggi $\left(>225^{\circ} \mathrm{C}\right)$. Hanya beberapa sistem yang mempunyai temperatur sedang $\left(125-225^{\circ} \mathrm{C}\right)$. Fluida panas bumi bertemperatur tinggi telah lama dimanfaatkan untuk PLTP, namun dengan perkembangan teknologi yang ada saat ini memungkinkan fluida bertemperatur sedang atau sumur-sumur bertekanan kecil untuk dimanfaatkan melalui PLTP skala kecil (small scale) (Sugiyono, 2012).

Teknologi PLTP sendiri terdiri atas empat jenis pembangkit, yaitu single-flash steam power plant, double-flash steam power plant, dry-steam power plant, dan binary cycle power plant (Dipippo, 2007):

a) Single-Flash Steam Power Plant

Jenis pembangkit ini merupakan jenis yang paling banyak digunakan. Istilah single-flash menunjukkan fluida panas bumi yang mengalami satu kali proses flashing. Proses flashing adalah proses pemisahan dari uap panas menjadi uap (steam) dan cairan (brine).

b) Double-Flash Steam Power Plant

Pembangkit jenis ini merupakan hasil penyempurnaan desain dari PLTP single-flash. Sistem double-flash dapat memproduksi uap panas dengan penambahan output sebesar 15-20\% dibandingkan sistem single-flash untuk kondisi fluida yang sama. Perbedaannya adalah pada sistem double-flash, uap panas hasil pemisahan di separator pertama masih digunakan untuk di flashing pada tahap selanjutnya. 
c) Dry-Steam Power Plant

Pembangkit jenis ini digunakan pada lapangan yang memiliki karakteristik uap panas yang didominasi oleh uap (steam) tanpa adanya cairan (brine).

d) Binary Cycle Power Plant

Jenis pembangkit ini dikombinasikan dengan sistem flash untuk memanfaatkan brine hasil buangan dari PLTP sistem flash pada lapangan yang didominasi oleh cairan (brine). Diperkirakan teknologi ini akan banyak dikembangkan di masa depan.

Tingginya biaya dan risiko pengeboran menjadi faktor penting untuk mengoptimalkan pengeboran sumur, terutama untuk sumur pertama pada pengembangan area prospek baru dimana terdapat ketidakpastian yang tinggi mengenai potensi sumber daya panas bumi. Dua jenis alternatif teknologi pemboran dalam industri panas bumi yang biasanya dipertimbangkan yaitu pemboran sumur lubang konvensional (conventional hole) dan pemboran sumur lubang kecil (deep slim hole). Penerapan satu atau lebih dari jenis alternatif teknologi pemboran ini disesuaikan dengan tujuan pengeboran dan faktor biaya. Pemboran conventional hole adalah pengeboran dengan diameter sumur standar yang dilakukan pada pemboran panas bumi pada umumnya, sedangkan pemboran deep slim hole adalah pengeboran sumur dengan diameter lebih kecil daripada yang digunakan pada conventional hole (Mackenzie et al, 2017). Penerapan teknologi pemboran deep slim hole sangat menarik untuk diterapkan karena diameter sumur yang lebih kecil daripada conventional hole memerlukan biaya yang lebih rendah sehingga dapat mengurangi risiko kegagalan pemboran.

\section{Hukum}

Harga jual listrik panas bumi saat ini berpatokan pada Permen ESDM No. 50
Tahun 2017 tentang Pemanfaatan Sumber Energi Terbarukan Untuk Penyediaan Tenaga Listrik. Namun, harga tersebut belum dapat diterima oleh seluruh pengembang panas bumi karena dinilai tidak memenuhi keekonomian proyek sehingga membutuhkan negosiasi antara PT PLN (Persero) dan pengembang panas bumi untuk pengembangan area prospek baru. Head of Agreement (HoA) digunakan untuk mengamendemen Power Purchase Agreement (PPA) yang telah ditandatangani sebelumnya oleh kedua belah pihak untuk lapangan eksisting. HoA merupakan tahap awal sebelum masuk ke tahap penyusunan PPA. Pemerintah seharusnya segera merevisi peraturan tersebut agar dapat memberikan kepastian harga jual listrik yang menarik bagi pengembang panas bumi sehingga investasi panas bumi akan meningkat.

6. Lingkungan

Permasalahan energi telah menjadi perhatian pemerintah Indonesia dalam beberapa tahun terakhir. Dibalik kecemasan atas kelangkaan energi di Indonesia, muncul angin segar dengan diundangkannya UU No. 21 Tahun 2014 yang merupakan revisi dari UU No. 27 Tahun 2003 tentang Panas Bumi. Perbedaan utama aturan baru ini dengan aturan sebelumnya terletak pada dikeluarkannya kegiatan panas bumi dari kegiatan pertambangan. Hal tersebut memberikan ruang pada kegiatan eksplorasi yang selama ini terhambat, dimana potensi panas bumi seringkali terdapat di wilayah hutan lindung dan hutan konservasi.

Pasal 24 UU No. 21 Tahun 2014 menyatakan bahwa dalam hal kegiatan pengusahaan panas bumi untuk pemanfaatan tidak langsung berada di kawasan hutan, pengembang panas bumi wajib mendapatkan Izin Pinjam Pakai Kawasan Hutan (IPPKH) untuk 
menggunakan kawasan hutan produksi dan kawasan hutan lindung, serta Izin Pemanfaatan Jasa Lingkungan Panas Bumi (IPJLB) untuk menggunakan kawasan hutan konservasi.

Namun tidak semua kawasan hutan yang menyimpan potensi panas bumi dapat dimanfaatkan. Terdapat batasanbatasan jenis hutan yang dapat dimanfaatkan untuk pengembangan potensi panas bumi. Kegiatan panas bumi dapat dilakukan di wilayah hutan konservasi kecuali pada hutan cagar alam dan zona inti, serta zona rimba pada taman nasional. Padahal temuan di lapangan menunjukkan potensi panas bumi sebagian besar berada di zona inti, sehingga harus diadakan usulan perubahan zonasi.

\section{Kondisi Internal Perusahaan}

Kondisi internal perusahaan diperoleh dari analisis rantai nilai. Rantai nilai perusahaan terdiri dari aktivitas utama dan aktivitas pendukung sesuai dengan matriks Porter's value chain (Gambar 2). Aktivitas-aktivitas tersebut yang berlangsung di perusahaan adalah sebagai berikut:

\section{Aktivitas Utama PT Geo Dipa Energi (Persero)}

1. Logistik ke Dalam

Kegiatan operasional pembangkitan energi listrik membutuhkan dukungan pasokan barang dan jasa tertentu secara terus menerus, mengingat energi listrik yang dihasilkan sesuai kontrak pembelian daya dengan PT PLN (Persero) tidak boleh terputus. Barang dan jasa terkait pada dasarnya terbagi atas barang dan jasa untuk kegiatan operasional dan pemeliharaan, barang dan jasa pendukung operasional dan pemeliharaan, serta barang dan jasa kebutuhan harian.

2. Operasi
PT Geo Dipa Energi (Persero) merupakan penyedia tenaga listrik dimana listrik yang dihasilkan merupakan hasil produksi dengan metode eksplorasi dan eksploitasi sumber panas bumi yang nantinya akan disalurkan ke PT PLN (Persero). Kegiatan operasi perusahaan dibagi menjadi 2 (dua), yaitu kegiatan operasi pada lapangan eksisting (Dieng dan Patuha) yang berada pada tahapan pemanfaatan, serta kegiatan operasi pada area prospek baru (Candradimuka, Arjuno Welirang, dan Candi Umbul Telomoyo) yang berada pada tahapan eksplorasi.

Kegiatan operasi pertama yang dilakukan pada lapangan eksisting (Dieng dan Patuha) antara lain adalah membangun sumur produksi, sumur injeksi brine, make up well, sumur injeksi kondensat, monitoring reservoir \& underground facility, operation and maintenance (O\&M) steam field, dan operation and maintenance (O\&M) power plant.

Kegiatan operasi kedua yang dilakukan pada area prospek baru (Candradimuka, Arjuno Welirang, dan Candi Umbul Telomoyo) adalah melakukan eksplorasi. Pekerjaan lapangan yang dilakukan adalah pemetaan geologi, analisis geokimia cairan, eksplorasi geofisika, dan pengeboran dangkal sumur eksplorasi. Setelah tahapan eksplorasi memberikan hasil positif, akan dilakukan kegiatan lain meliputi eksplorasi geofisika yang lebih terfokus, pengeboran sumur eksplorasi yang lebih dalam, analisis sampel kimiawi fluida, dan analisis data kelayakan. Aktivitas ini harus dilakukan sedetail mungkin karena memiliki ketidakpastian yang tinggi dan juga menggunakan ekuitas perusahaan.

3. Logistik ke Luar

Hasil produksi perusahaan berupa listrik yang dibeli oleh PT PLN (Persero) langsung tersambung dengan sistem 
interkoneksi Jawa-Madura-Bali (Jamali). Aktivitas logistik keluar perusahaan adalah saat mendistribusikan listrik dari power plant ke jaringan transmisi PT PLN (Persero) melalui switch yard. Listrik yang dibangkitkan dari power plant tegangannya akan dinaikkan oleh transformator (trafo step up) sebelum dikirimkan ke switch yard agar tidak terjadi loss tegangan saat di transformasikan. Pada switch yard terdapat 2 (dua) buah kwH meter, yaitu milik PT PLN (Persero) dan milik PT Geo Dipa Energi (Persero) yang berguna untuk mengukur jumlah listrik yang telah di transformasikan ke jaringan transmisi PT PLN (Persero).

4. Pemasaran dan Penjualan

Aktivitas pemasaran dan penjualan perusahaan tidak ditangani oleh bagian khusus, dikarenakan adanya single buyer, dalam hal ini PT PLN (Persero). PT PLN (Persero) merupakan satu-satunya perusahaan penyalur energi listrik di Indonesia. Dalam rangka memenuhi kebutuhan tenaga listrik nasional, pemanfaatan energi terbarukan, dan penggunaan energi ramah lingkungan, serta didukung dengan Permen ESDM No. 17 Tahun 2014 tentang Pembelian Tenaga Listrik dari PLTP dan Uap Panas Bumi Untuk PLTP Oleh PT Perusahaan Listrik Negara (Persero), pemerintah mewajibkan PT PLN (Persero) untuk membeli tenaga listrik dari PLTP.

\section{Pelayanan}

Aktivitas pelayanan kepada pelanggan, dalam hal ini PT PLN (Persero) berupa penyesuaian $\mathrm{kWh}$ meter antara milik PT PLN (Persero) dan milik PT Geo Dipa Energi (Persero) secara berkala. Hal ini bertujuan untuk mendapat kecocokan data jumlah listrik yang telah di transformasikan ke jaringan transmisi PT PLN (Persero).
Pelayanan lain yang diberikan adalah penyesuaian tegangan pada kondisi tertentu, misalnya saat musim hujan dan saat diselenggarakan event kenegaraan. Saat musim hujan, beban listrik yang dihasilkan dari pembangkit listrik tenaga air (PLTA) akan besar, sehingga PT PLN (Persero) akan meminta perusahaan untuk mengurangi beban listrik dari PLTP. Sedangkan saat diselenggarakan event kenegaraan seperti ASEAN Games yang membutuhkan daya listrik besar, PT PLN (Persero) akan meminta perusahaan untuk meningkatkan daya dan memastikan pasokan listrik tetap aman selama event berlangsung.

Aktivitas Pendukung PT Geo Dipa Energi (Persero)

1. Infrastruktur Perusahaan

Infrastruktur PT Geo Dipa Energi (Persero) meliputi aktivitas-aktivitas seperti general management, public affair, perencanaan, keuangan, akuntansi, hukum, dan relasi pemerintah yang diperlukan untuk mendukung kinerja seluruh rantai nilai. Melalui infrastruktur ini, perusahaan berusaha dengan efektif dan konsisten mengidentifikasi peluang dan ancaman, mengidentifikasi sumber daya dan kapabilitas, serta mendukung kompetensi inti.

2. Manajemen Sumber Daya Manusia

Manajemen SDM sangat diperlukan untuk pencapaian target produksi perusahaan. Manajemen SDM yang dilakukan PT Geo Dipa Energi (Persero) diantaranya adalah perekrutan karyawan, penempatan, reward and punishment, pelatihan dan pengembangan, pemberhentian pegawai, serta penggajian.

PT Geo Dipa Energi (Persero) telah melakukan usaha-usaha perekrutan SDM baik untuk di sisi hulu (eksplorasi) maupun di sisi hilir (pemanfaatan). Walaupun perusahaan memiiliki SDM berpengalaman di sisi hilir lapangan Dieng 
dan Patuha, namun kondisi SDM saat ini di sisi hulu belum cukup untuk memenuhi kebutuhan perusahaan dalam mengembangkan area prospek baru (Candradimuka, Arjuno Welirang, dan Candi Umbul Telomoyo).

3. Pengembangan Teknologi

Sejalan dengan usaha perusahaan untuk terus meningkatkan pemanfaatan energi panas bumi sebagai pembangkit listrik, teknologi panas bumipun terus dikembangkan. Perusahaan terus meningkatkan teknik eksplorasi untuk dapat membuktikan cadangan sebesarbesarnya dengan biaya yang sekecilkecilnya melalui teknik pemboran yang aman, efektif, dan efisien. Selain di sisi pemboran, di sisi pembangunan pembangkitpun dilakukan pengembangan teknologi agar dapat memaksimalkan kapasitas pembangkit dan meningkatkan kehandalan operasi.

Teknik pemboran yang saat ini sedang dikembangkan perusahaan adalah pemboran deep slim hole. Pemboran deep slim hole adalah pengeboran sumur dengan diameter lebih kecil daripada yang digunakan pada conventional hole $(<15 \mathrm{~cm})$. Diameter yang lebih kecil membantu mengurangi waktu dan biaya karena rig yang digunakan lebih kecil, sehingga membutuhkan biaya transportasi dan persiapan lahan yang lebih sedikit. Selain itu, diameter yang lebih kecil memerlukan alat bor, casing, dan pekerjaan cementing yang lebih murah (Finger dan Jacobson, 2000).

Di sisi pembangunan pembangkit, saat ini perusahaan sedang mengembangkan teknologi PLTP binary pada lapangan eksisting (Dieng dan Patuha) sebagai komplimenter dari PLTP eksisting dengan memanfaatkan energi panas dari brine hasil produksi. PLTP sistem binary cycle biasanya diterapkan untuk lapangan panas bumi dengan entalpi rendah atau menengah, dimana cairan yang dihasilkan dari uap (brine) dimanfaatkan sebelum diinjeksikan ke dalam sumur injeksi untuk memanaskan working fluid (biasanya senyawa organik seperti isobutana yang mempunyai titik didih rendah) pada heat exchanger. Working fluid kemudian menjadi panas dan menghasilkan uap yang akan digunakan untuk memutar turbin dan selanjutnya menggerakkan generator untuk menghasilkan listrik. Cairan yang dihasilkan di heat exchanger ini disebut secondary (binary) fluid. Binary fluid yang keluar dari heat exchanger dikembalikan ke reservoir dengan cara diinjeksikan melalui sumur injeksi. PLTP jenis ini memanfaatkan uap panas bumi basah (dua fasa) yang tidak bisa digunakan pada PLTP konvensional, sehingga dapat meningkatkan efisiensi dan menambah kapasitas pembangkitan. PLTP ini dapat digunakan sebagai model pemanfaatan sumur panas bumi dua fasa dengan dominasi cairan (brine) yang menjadi karakteristik kebanyakan sumber panas bumi di Indonesia.

Selain itu, perusahaan juga sedang mengembangan teknologi PLTP skala kecil (small scale) dengan memanfaatkan uap panas bumi yang belum tersalurkan dari sumur-sumur idle, sumur berproduksi rendah, maupun excess steam. Di lapangan ditemui beberapa sumur yang tekanannya tidak sesuai target. Sumur inilah yang akan dimanfaatkan dengan membangun pembangkit di dekat sumur itu sendiri, tepatnya pada geothermal well head unit. Meskipun tekanannya tidak terlalu besar, namun uapnya dapat dimanfaatkan untuk memutar turbin sehingga dapat menambah kapasitas pembangkitan.

\section{Pembelian}

Aktivitas pembelian dilakukan untuk menyediakan barang dan jasa kebutuhan operasional perusahaan secara tepat waktu dengan biaya serendah mungkin, 
serta mutu yang baik. Ketidaksesuaian mutu barang/jasa menjadi dasar pertimbangan dalam pemilihan penyedia barang/jasa pada proses pembelian berikutnya. Untuk menjaga kualitas produksi, perusahaan melakukan evaluasi berkala terhadap rekanan penyedia barang/jasa. Hal ini penting mengingat kualitas uap hasil produksi sangat tergantung pada kualitas barang/jasa yang digunakan. Oleh karenanya, perusahaan melakukan proses seleksi yang cukup ketat terhadap rekanan agar diperoleh pemasok yang sejalan dengan kebutuhan operasional jangka panjang perusahaan.

Gambar 2

Rantai Nilai PT Geo Dipa Energi (Persero)

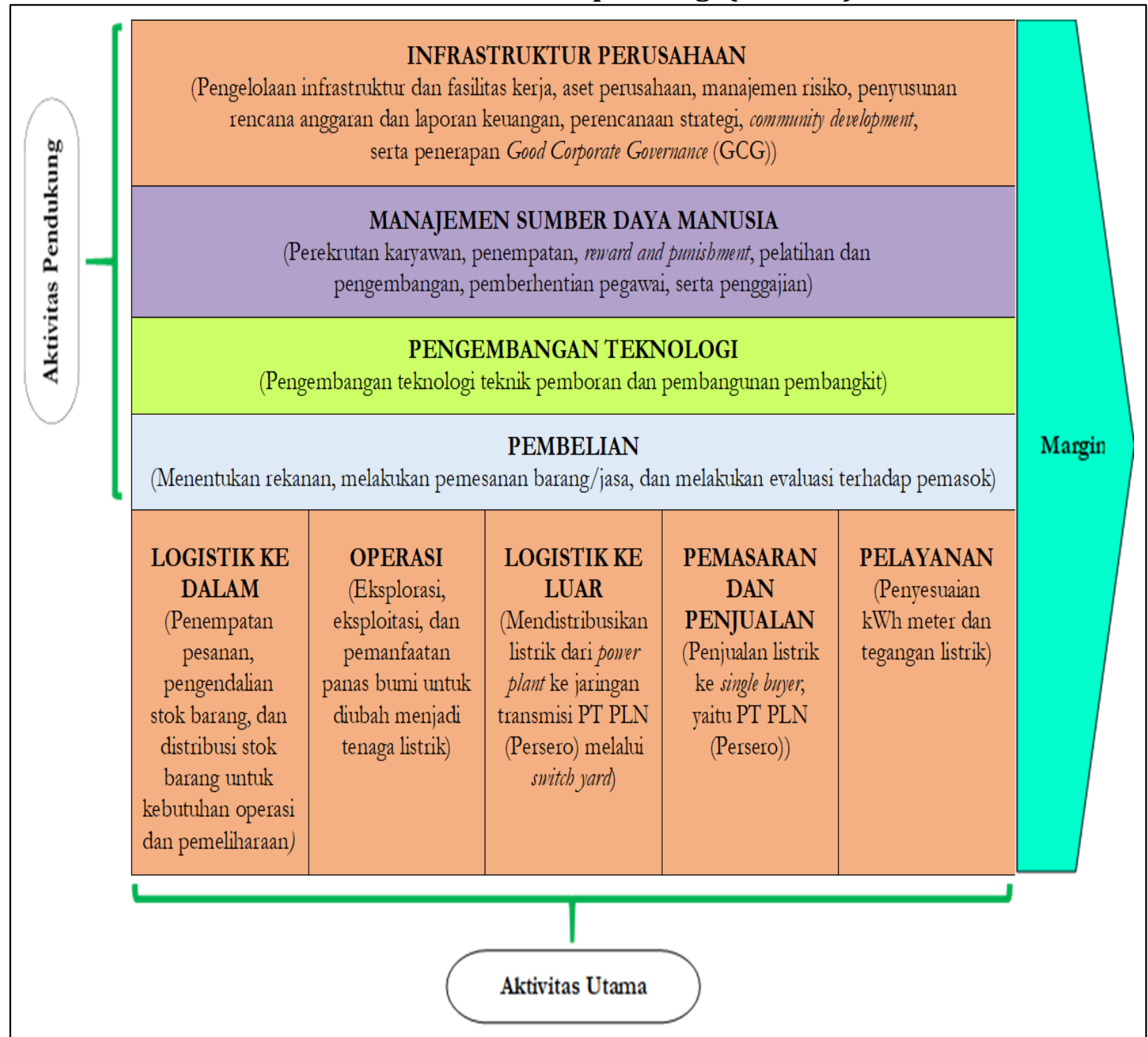

\section{Analisis Faktor-Faktor Strategis}

Faktor-faktor strategis eksternal dan internal yang berhasil diidentifikasi kemudian dikelompokkan dalam empat kelompok, yaitu kekuatan, kelemahan, peluang, dan ancaman. Kekuatan dan kelemahan di identifikasi dari analisis lingkungan internal, sedangkan peluang 
dan ancaman di identifikasi dari analisis

lingkungan eksternal yang dapat

dirangkum pada Tabel 5.

\section{Tabel 5}

Faktor Strategis Eksternal dan Internal PT Geo Dipa Energi (Persero)

Faktor Strategis Eksternal dan Internal

\section{Peluang}

1. Kesempatan untuk pengembangan baru melalui penugasan BUMN (area prospek Candradimuka, Arjuno Welirang, dan Candi Umbul Telomoyo)

2. Potensi mendapatkan grant/hibah dana dari lender untuk tahapan eksplorasi

3. Penggunaan teknologi pemboran yang lebih efektif dan efisien (deep slim hole)

4. Perkembangan teknologi pembangkit (binary cycle dan small scale) yang dapat menambah kapasitas pembangkitan

\footnotetext{
Ancaman

1. Belum ada kepastian Head of Agreement (HoA) dari PT PLN (Persero)

2. Tidak diperoleh pinjaman dari lender (soft loan) untuk tahapan eksploitasi

3. Kejelasan regulasi kehutanan dan perpajakan terkait pengelolaan panas bumi

4. Besarnya sumber daya panas bumi setelah eksplorasi lebih rendah dari rencana awal

\section{Kekuatan}

1. Status BUMN di bawah Kementerian Keuangan

2. PT PLN (Persero) merupakan shareholder sekaligus buyer perusahaan

3. Porsi equity relatif secured dari kas internal dan PMN (Penyertaan Modal Negara)

4. Pengalaman operasi dan pemeliharaan (O\&M) di sisi hilir Lapangan Dieng dan Patuha

5. Bankable untuk melakukan pengembangan baru, namun dibatasi oleh ketersediaan aset
}

\section{Kelemahan}

1. Penerapan manajemen risiko yang belum optimal dan manajemen aset yang belum terintegrasi dengan manajemen mutu

2. Kompetensi perusahaan dalam bidang pengeboran belum dimiliki secara utuh

3. Dengan hanya menggunakan dana internal, perusahaan sulit untuk memenuhi kewajiban porsi equity dalam rencana pengembangan

4. Komposisi SDM belum seimbang dengan kebutuhan perusahaan (core dan non core)

\section{Alternatif Strategi PT Geo Dipa Energi (Persero)}

Analisis matriks TOWS merupakan keberlanjutan dari analisis faktor-faktor strategis eksternal dan internal, yaitu dengan mencocokkan faktor peluang, ancaman, kekuatan, dan kelemahan untuk memperoleh alternatif strategi bagi perusahaan. Dari tahap pencocokan yang dilakukan, didapatkan empat kelompok alternatif strategi yaitu: strategi SO (Strengths-Opportunities), ST (StrengthsThreats), WO (Weaknesses-Opportunities), dan WT (Weaknesses-Threats) (Tabel 6). 


\section{Tabel 6 \\ Matriks TOWS PT Geo Dipa Energi (Persero)}

\begin{tabular}{|c|c|c|}
\hline FAKTOR INTERNAL & $\begin{array}{l}\text { KEKUATAN (S) } \\
\text { 1. Status BUMN di bawah } \\
\text { Kementrian Keuangan (S1) } \\
\text { 2. PT PLN (Persero) merupakan } \\
\text { shareholder sekaligus buyer } \\
\text { perusahaan (S2) } \\
\text { 3. Porsi equity relatif secured dari } \\
\text { kas internal dan PMN } \\
\text { (Penyertaan Modal Negara) } \\
\text { (S3) } \\
\text { 4. Pengalaman operasi dan } \\
\text { pemeliharaan (O\&M) di sisi } \\
\text { hilir lapangan Dieng dan } \\
\text { Patuha (S4) } \\
\text { 5. Bankable untuk melakukan } \\
\text { pengembangan baru, namun } \\
\text { dibatasi oleh ketersediaan aset } \\
\text { (S5) }\end{array}$ & $\begin{array}{l}\text { KELEMAHAN (W) } \\
\text { 1. Penerapan manajemen risiko } \\
\text { yang belum optimal dan } \\
\text { manajemen aset yang belum } \\
\text { terintegrasi manajemen mutu } \\
\text { (W1) } \\
\text { 2. Kompetensi perusahaan dalam } \\
\text { bidang pengeboran belum } \\
\text { dimiliki secara utuh (W2) } \\
\text { 3. Dengan hanya menggunakan } \\
\text { dana internal, perusahaan sulit } \\
\text { untuk memenuhi kewajiban } \\
\text { porsi equity dalam rencana } \\
\text { pengembangan (W3) } \\
\text { 4. Komposisi SDM belum } \\
\text { seimbang dengan kebutuhan } \\
\text { perusahaan (core dan non core) } \\
\text { (W4) }\end{array}$ \\
\hline $\begin{array}{l}\text { PELUANG (0) } \\
\text { 1. Kesempatan untuk } \\
\text { pengembangan baru melalui } \\
\text { penugasan BUMN (area } \\
\text { prospek Candradimuka, Arjuno } \\
\text { Welirang, dan Candi Umbul } \\
\text { Telomoyo) (01) } \\
\text { 2. Potensi mendapatkan } \\
\text { grant/hibah dana dari lender } \\
\text { untuk tahapan eksplorasi (O2) } \\
\text { 3. Penggunaan teknologi } \\
\text { pemboran yang lebih efektif } \\
\text { dan efisien (deep slim hole) } \\
\text { (O3) } \\
\text { 4. Perkembangan teknologi } \\
\text { pembangkit (binary cycle dan } \\
\text { small scale) yang dapat } \\
\text { menambah kapasitas } \\
\text { pembangkitan (04) }\end{array}$ & $\begin{array}{l}\text { STRATEGI S-O } \\
\text { 1. Menggunakan status BUMN } \\
\text { sebagai akses untuk } \\
\text { mempermudah mendapatkan } \\
\text { pendanaan dan hibah dalam } \\
\text { pengembangan area prospek } \\
\text { baru (S1,S2, S3,S4, S5, O1, O2) } \\
\text { 2. Melakukan kerjasama dengan } \\
\text { mitra kompeten (lokal dan } \\
\text { asing) untuk pengembangan } \\
\text { teknologi dan keahlian yang } \\
\text { lebih handal dan efisien (S2, S4, } \\
\text { O3, O4) }\end{array}$ & $\begin{array}{l}\text { STRATEGI W-O } \\
\text { 1.Meningkatkan keunggulan } \\
\text { pengelolaan SDM, khususnya } \\
\text { untuk kebutuhan core di bidang } \\
\text { pengeboran (W2, W4, O2, O3) } \\
\text { 2. Mencari mitra yang kompetitif } \\
\text { sebagai subkontraktor } \\
\text { pengeboran (W2, W4, 01, 03) } \\
\text { 3. Menerapkan dan mensertifikasi } \\
\text { sistem manajemen terintegrasi } \\
\text { mencakup ISO 9000, 31000, dan } \\
\text { 55000 (W1, W2, W3, W4, 01,02, } \\
\text { 03, 04) }\end{array}$ \\
\hline $\begin{array}{l}\text { ANCAMAN (T) } \\
\text { 1. Belum ada kepastian Head of } \\
\text { Agreement (HoA) dari PT PLN } \\
\text { (Persero) (T1) } \\
\text { 2. Tidak diperoleh pinjaman dari } \\
\text { lender (soft loan) untuk } \\
\text { tahapan eksploitasi (T2) } \\
\text { 3. Kejelasan regulasi kehutanan } \\
\text { dan perpajakan terkait } \\
\text { pengelolaan panas bumi (T3) } \\
\text { 4. Besarnya sumber daya panas } \\
\text { bumi setelah eksplorasi lebih } \\
\text { rendah dari rencana awal (T4) }\end{array}$ & $\begin{array}{l}\text { STRATEGI S-T } \\
\text { 1. Bekerja sama dengan Asosiasi } \\
\text { Panasbumi Indonesia (API) } \\
\text { untuk menyiapkan masukan } \\
\text { dan usulan kepada Pemerintah } \\
\text { terkait kejelasan regulasi (S1, } \\
\text { S2, T3) } \\
\text { 2. Melakukan koordinasi intensif } \\
\text { dengan PLN dalam negosiasi } \\
\text { pengembangan area prospek } \\
\text { baru (S1, S2, T1) } \\
\text { 3. Menerapkan Lean } \\
\text { Manufacturing untuk } \\
\text { peningkatan efisiensi dan mutu } \\
\text { kegiatan operasional } \\
\text { perusahaan (S4, T1, T4) }\end{array}$ & $\begin{array}{l}\text { STRATEGI W-T } \\
\text { 1. Menerapkan sekuritisasi aset } \\
\text { dalam pengajuan pinjaman } \\
\text { pendanaan untuk tahapan } \\
\text { eksploitasi }(\mathrm{W} 3, \mathrm{~T} 2)\end{array}$ \\
\hline
\end{tabular}




\section{Prioritas Strategi}

Hasil analisis matriks TOWS menghasilkan beberapa alternatif strategi yang kemudian diolah menggunakan metode Analytic Hierarchy Process (AHP) untuk memperoleh prioritas strategi.

Berdasarkan hasil diskusi dan saran yang diberikan oleh para responden pakar, hierarki untuk menentukan prioritas strategi pada penelitian ini terdiri dari lima tingkatan. Tingkat pertama adalah fokus yang ingin dicapai, tingkat kedua adalah aktor yang berperan dalam pengambilan keputusan strategi, tingkat ketiga adalah faktor yang mempengaruhi keberhasilan penerapan strategi, tingkat keempat adalah kriteria yang menjadi syarat/acuan dasar dalam memilih strategi, dan tingkat kelima adalah alternatif strategi yang harus dievaluasi dan dibandingkan.

Setelah pembobotan yang dilakukan oleh responden pakar, selanjutnya angka yang diperoleh akan diolah menggunakan program Expert Choice 11. Program ini digunakan untuk mensistesa pengaruh aktor, faktor, dan kriteria terhadap alternatif strategi yang akan digunakan untuk menentukan prioritas strategi terhadap fokus optimalisasi biaya pokok penyediaan pembangkitan di PT Geo Dipa Energi (Persero). Hasil pengolahan bobot dan prioritas hierarki PT Geo Dipa Energi (Persero) dapat dilihat pada Gambar 3.

\section{Gambar 3}

\section{Hasil Pengolahan Bobot dan Prioritas Hierarki PT Geo Dipa Energi (Persero)}

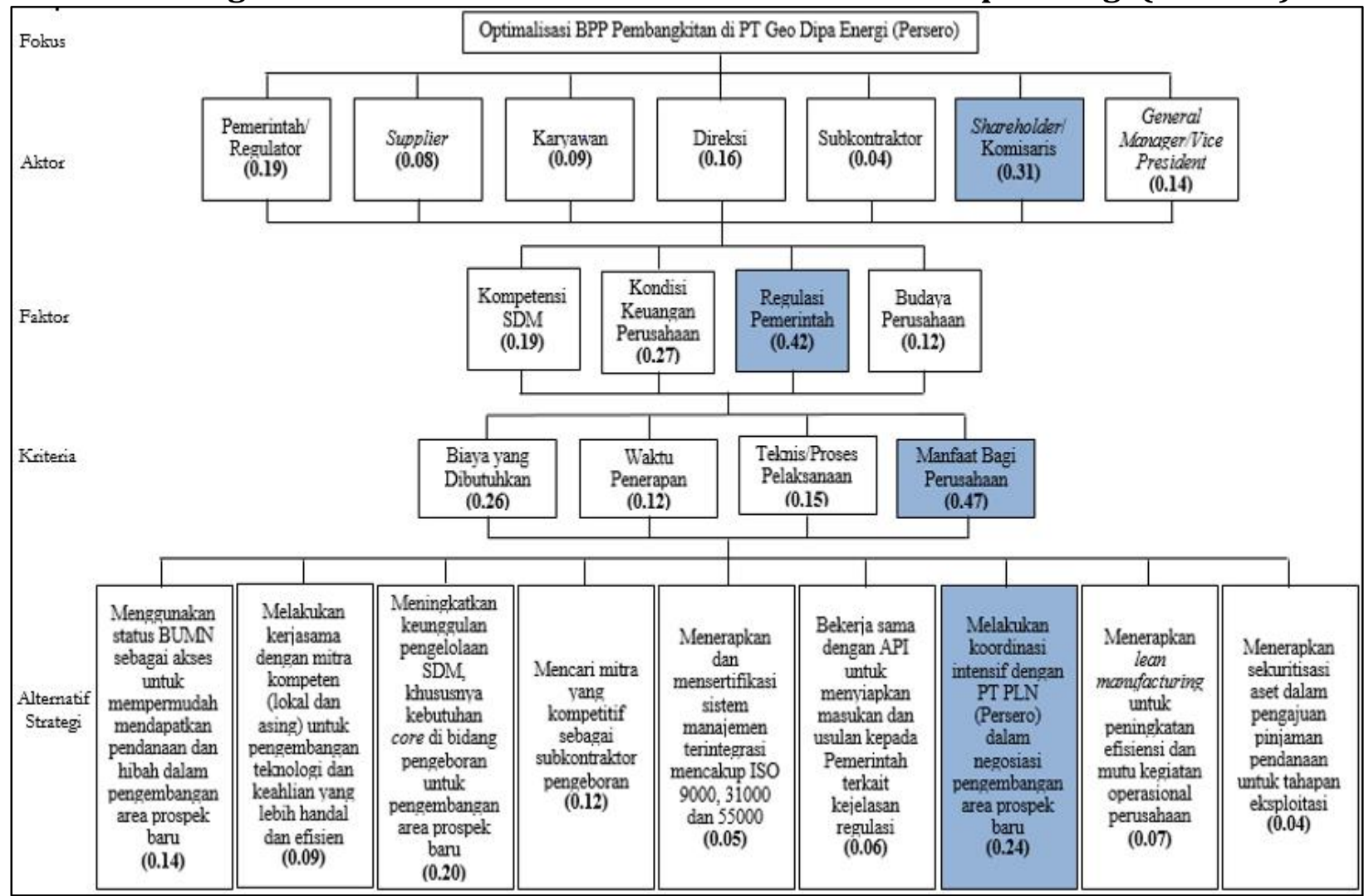

Hasil analisis vertikal berdasarkan prioritas masing-masing tingkatan hierarki dapat dijelaskan sebagai berikut. Prioritas strategi yang dipilih dalam mencapai fokus optimalisasi biaya pokok penyediaan pembangkitan di PT Geo Dipa Energi (Persero) adalah dengan melakukan koordinasi intensif dengan PT 
PLN (Persero) dalam negosiasi pengembangan area prospek baru. Strategi tersebut dipilih didasarkan pada kriteria manfaat bagi perusahaan, yaitu dapat membantu perusahaan dalam memperoleh kepastian harga jual listrik kepada PT PLN (Persero) guna menyusun rencana pengembangan dan arus kas perusahaan. Strategi tersebut juga dipilih dengan mempertimbangkan faktor regulasi pemerintah, yakni terkait regulasi panas bumi yang masih sering mengalami inkonsistensi yang dapat mengancam kelangsungan bisnis perusahaan dalam rencana pengembangan area prospek baru. Selanjutnya aktor yang paling berperan dalam menjalankan strategi prioritas tersebut adalah shareholder/komisaris dikarenakan berperan sebagai pihak tertinggi di perusahaan yang memiliki kekuasaan untuk menentukan apakah suatu kebijakan akan diterapkan dalam perusahaan berdasarkan koordinasi dengan dewan direksi.

\section{KESIMPULAN DAN IMPLIKASI KEBIJAKAN \\ Kesimpulan}

Analisis matriks TOWS menghasilkan sembilan alternatif strategi yaitu (1) menggunakan status BUMN sebagai akses untuk mempermudah mendapatkan pendanaan dan hibah dalam pengembangan area prospek baru, (2) melakukan kerjasama dengan mitra kompeten (lokal dan asing) untuk pengembangan teknologi dan keahlian yang lebih handal dan efisien, (3) meningkatkan keunggulan pengelolaan SDM, khususnya kebutuhan core di bidang pengeboran untuk pengembangan area prospek baru, (4) mencari mitra yang kompetitif sebagai subkontraktor pengeboran, (5) menerapkan dan mensertifikasi sistem manajemen terintegrasi mencakup ISO 9000, 31000, dan 55000, (6) bekerja sama dengan Asosiasi Panasbumi Indonesia (API) untuk menyiapkan masukan dan usulan kepada Pemerintah terkait kejelasan regulasi, (7) melakukan koordinasi intensif dengan PT PLN (Persero) dalam negosiasi pengembangan area prospek baru, (8) menerapkan lean manufacturing untuk peningkatan efisiensi dan mutu kegiatan operasional perusahaan, dan (9) menerapkan sekuritisasi aset dalam pengajuan pinjaman pendanaan untuk tahapan eksploitasi.

Prioritas strategi yang terpilih dalam mencapai fokus optimalisasi biaya pokok penyediaan pembangkitan di PT Geo Dipa Energi (Persero) berdasarkan analisis AHP adalah melakukan koordinasi intensif dengan PT PLN (Persero) dalam negosiasi pengembangan area prospek baru dengan bobot sebesar 0.24 .

\section{Implikasi Manajerial}

Tahapan penting setelah perumusan strategi adalah implementasi strategi. Implementasi strategi adalah proses dimana manajemen mewujudkan strategi dan kebijakannya dalam tindakan melalui pengembangan program/rencana aksi agar dapat diimplementasikan secara efektif oleh perusahaan. Adapun kesembilan alternatif strategi yang direkomendasikan beserta rencana aksinya dapat dirangkum pada Tabel 7 . 


\section{Tabel 7}

\section{Implikasi Manajerial Dari Alternatif Strategi Yang Dihasilkan}

\begin{tabular}{|c|c|c|c|}
\hline Peringkat & Rekomendasi Strategi & Rencana Aksi & Key Performance Indicator \\
\hline 1 & $\begin{array}{l}\text { Melakukan koordinasi intensif dengan PT } \\
\text { PLN (Persero) dalam negosiasi } \\
\text { pengembangan area prospek baru }\end{array}$ & $\begin{array}{l}\text { Menyusun skema price curve untuk diajukan } \\
\text { kepada } \\
\text { PT PLN (Persero) guna negosiasi harga jual listik }\end{array}$ & $\begin{array}{l}\text { Tercapai kesepakatan head of } \\
\text { agreement }(\mathrm{HoA})\end{array}$ \\
\hline 2 & $\begin{array}{l}\text { Meningkatkan keunggulan pengelolaan SDM, } \\
\text { khususnya kebutuhan core di bidang } \\
\text { pengeboran untuk pengembangan area } \\
\text { prospek baru }\end{array}$ & $\begin{array}{l}\text { Memberikan kesempatan kepada seluruh SDM } \\
\text { perusahaan untuk mengikuti pelatihan, } \\
\text { pendidikan, sertifikasi, dan perkembangan } \\
\text { teknologi di bidang pemboran. }\end{array}$ & $\begin{array}{l}\text { - Tersedianya SDM yang } \\
\text { memiliki sertifikasi } \\
\text { pemboran } \\
\text { - Jumlah SDM di bidang } \\
\text { pemboran tersedia sesuai } \\
\text { kebutuhan perusahaan }\end{array}$ \\
\hline 3 & $\begin{array}{l}\text { Menggunakan status BUMN sebagai akses } \\
\text { untuk mempermudah mendapatkan } \\
\text { pendanaan dan hibah dalam pengembangan } \\
\text { area prospek baru }\end{array}$ & $\begin{array}{l}\text { Me-leverage status BUMN dalam } \\
\text { mengembangkan area prospek baru }\end{array}$ & $\begin{array}{l}\text { Memperoleh kecukupan } \\
\text { pendanaan untuk } \\
\text { pengembangan area prospek } \\
\text { baru }\end{array}$ \\
\hline 4 & $\begin{array}{l}\text { Mencari mitra yang kompetitif sebagai } \\
\text { subkontraktor pengeboran }\end{array}$ & $\begin{array}{l}\text { Mengadakan lelang atau pemilihan langsung } \\
\text { guna memperoleh tenaga ahli/mitra pelaksana } \\
\text { jasa pemboran }\end{array}$ & $\begin{array}{l}\text { Penyelesaian pekerjaan } \\
\text { pengeboran yang berkualitas } \\
\text { dan tepat waktu }\end{array}$ \\
\hline 5 & $\begin{array}{l}\text { Melakukan kerjasama dengan mitra } \\
\text { kompeten (lokal dan asing) untuk } \\
\text { pengembangan teknologi dan keahlian yang } \\
\text { lebih handal dan efisien }\end{array}$ & $\begin{array}{l}\text { Mengadakan lelang atau pemilihan langsung } \\
\text { guna mendapatkan mitra kompeten yang } \\
\text { memiliki kemampuan teknologi terbaru di } \\
\text { bidang pemboran dan pembangkitan }\end{array}$ & $\begin{array}{l}\text { Pekerjaan pemboran lebih } \\
\text { efektif dan efieisen, serta } \\
\text { kapasitas pembangkitan } \\
\text { meningkat }\end{array}$ \\
\hline 6 & $\begin{array}{l}\text { Menerapkan lean manufacturing untuk } \\
\text { peningkatan efisiensi dan mutu kegiatan } \\
\text { operasional perusahaan }\end{array}$ & $\begin{array}{l}\text { Mengadakan pelatihan dan training kepada } \\
\text { karyawan untuk memberikan orientasi } \\
\text { dalam melakukan lean manufacturing } \\
\text { - Mendesain sistem pembangkitan yang } \\
\text { mudah dipahami oleh setiap karyawan guna } \\
\text { meminimalisir waste dan human error }\end{array}$ & $\begin{array}{l}\text { Mampu mengurangi waste pada } \\
\text { proses pembangkitan listrik }\end{array}$ \\
\hline 7 & $\begin{array}{l}\text { Bekerja sama dengan Asosiasi Panasbumi } \\
\text { Indonesia (API) untuk menyiapkan masukan } \\
\text { dan usulan kepada Pemerintah terkait } \\
\text { kejelasan regulasi }\end{array}$ & $\begin{array}{l}\text { Berkordinasi antar pengembang panas bumi } \\
\text { lainnya dalam menyiapkan masukan kepada } \\
\text { Pemerintah tekait aspek regulasi yang dapat } \\
\text { menggagalkan pengembangan panas bumi }\end{array}$ & $\begin{array}{l}\text { Tercapainya kepastian aspek } \\
\text { kelayakan usaha }\end{array}$ \\
\hline 8 & $\begin{array}{l}\text { Menerapkan dan mensertifikasi sistem } \\
\text { manajemen terintegrasi mencakup IS0 9000, } \\
\text { 31000, dan } 55000\end{array}$ & $\begin{array}{l}\text { - Melakukan sertifikasi ISO } 9000 \text { (manajemen } \\
\text { mutu), ISO } 31000 \text { (manajemen risiko), dan } \\
\text { IS0 } 55000 \text { (sistem manajemen aset) } \\
\text { - Benchmark penerapan manajemen mutu, } \\
\text { manajemen risko, dan manajemen asset } \\
\text { dengan pengembang panas bumi lainnya }\end{array}$ & $\begin{array}{l}\text { - } \text { Memperoleh sertifikasi ISO } \\
\text { 9000,31000, dan } 55000 \\
\text { - Tercapaianya sistem } \\
\text { manajemen terintegrasi }\end{array}$ \\
\hline 9 & $\begin{array}{l}\text { Menerapkan sekuritisasi aset dalam } \\
\text { pengajuan pinjaman pendanaan untuk } \\
\text { tahapan eksploitasi }\end{array}$ & $\begin{array}{l}\text { Menjaminkan aset keuangan berupa piutang } \\
\text { dari Energy Sales Contract (ESC) PLTP Dieng-1 } \\
\text { dan Patuha-1 kepada lender }\end{array}$ & $\begin{array}{l}\text { Memperoleh pinjaman dana } \\
\text { dari lender }\end{array}$ \\
\hline
\end{tabular}

\section{Keterbatasan Penelitian}

Penelitian ini dibatasi pada lingkup bahasan yang berfokus pada aktivitas rantai nilai pada PT Geo Dipa Energi (Persero) dalam menciptakan strategi optimalisasi biaya pokok penyediaan pembangkitan dengan menggunakan kekuatan dan meminimalkan kelemahan untuk memanfaaatkan peluang serta mengatasi ancaman yang dihadapi 
perusahaan. Implementasi dari hasil prioritas strategi yang terpilih nantinya diserahkan kepada PT Geo Dipa Energi (Persero).

\section{Agenda Penelitian Kedepan}

Keterbatasan penelitian ini dapat menjadi sumber referensi untuk penelitian kedepannya. Adapun beberapa saran dari hasil penelitian ini adalah sebagai berikut: (1) Bagi perusahaan, alternatif strategi ini kiranya dapat dipertimbangkan melalui penerapan rencana aksi sebagaimana diuraikan dalam penelitian ini sehingga akan memiliki dampak terhadap peningkatan kinerja perusahaan; (2) Bagi pemerintah, perlu dilakukan penataan berbagai regulasi di sektor panas bumi agar dapat memberikan kepastian usaha bagi keberlanjutan pengembangan panas bumi di masa mendatang; (3) Untuk penelitian selanjutnya, kondisi finansisal PT Geo Dipa Energi (Persero) terkait dengan risiko tinggi yang dihadapi dalam pengembangan panas bumi dapat menjadi topik menarik untuk disuguhkan di masa mendatang sehingga nantinya dapat menjadi rekomendasi bagi pemangku kepentingan dalam membuat keputusan.

\section{REFERENSI}

Armstead, H.C.H. (1983). Geothermal Energy: Its Past, Present and Future Contribution to the Energy Needs of Man, 2nd Edition. New York, US: E. \& F.N Spon

Darma, S., Harsoprayitno, S., Setiawan, B., Hadyanto, Sukhyar, R., Soedibjo, A.W., Ganefianto, N., \& Stimac, J. (2010). Geothermal energy update: geothermal energy development and utilization in Indonesia. Proceedings of World Geothermal Congress, 2010. World Geothermal Congress 2010. (1-13). Tersedia pada https://www.geothermal-energy.org/

David, F.R. 2011. Strategic Management: Concepts and Cases, 13th Edition. New Jersey, US: Pearson Education, Inc

Dipippo, R. (2007). Geothermal power plant, principles, applications, case studies and environmental impact, 2nd Edition. Massachusetts, US: Elsevier, Ltd

Direktorat Panas Bumi. (2017). Potensi Panas Bumi Indonesia. Jakarta, ID: Kementerian Energi dan Sumber Daya Mineral

Fandari, A.E., Daryanto, A., \& Suprayitno, G. (2014). Pengembangan energi panas bumi yang berkelanjutan. Jurnal Ilmiah Semesta Teknika. 17(1), 68-82

Finger, J., \& Jacobson, R., (2000). Slimhole drilling, logging, and completion techology - an update. Proceedings of World Geothermal Congress, 2000. World Geothermal Congress 2000. (2335-2339). Tersedia pada https://www.geothermal-energy.org/

Kementerian Energi dan Sumber Daya Mineral. (2015). Renstra KESDM 2015-2019. Jakarta, ID: Kementerian Energi dan Sumber Daya Mineral

Latifah, M., \& Gusmayanti, I. (2012). Optimalisasi pemanfaatan panas bumi sebagai sumber energi pembangkit listrik untuk mencapai keamanan energi. The 2012 ASC Paper 
Competition, 2012. Asian Science Camp 2012. (11-30). Tersedia pada https://asc2012.ort.org.il/

Mackenzie, K.M., Ussher, G.N.H, Libbey, R.B., Quinlivan, P.F., Dacanay, J.U., Bogie, I., \& Jacobs. (2017). Use of deep slimhole drilling for geothermal exploration. Proceedings The 5th Indonesia International Geothermal Convention \& Exhibition (IIGCE), 2017. Indonesia International Geothermal Convention \& Exhibition 2017. (1-16). Tersedia pada http://iigce.com/technical-paper/

Marimin, \& Maghfiroh, N. (2011). Aplikasi Teknik Pengambilan Keputusan dalam Manajemen Rantai Pasok. Bogor, ID: PT Penerbit IPB Press

Mary, R.T., Armawi, A., Hadna, A.H., \& Pitoyo, A.J. (2017). Panas bumi sebagai harta karun untuk menuju ketahanan energi. Jurnal Ketahanan Nasional. 23(2), 217-237

[Permen] Peraturan Menteri. Peraturan Menteri Keuangan No. 142/PMK.010/2015 tentang Perlakuan Pajak Pertambahan Nilai Dan Pajak Penjualan Atas Barang Mewah Atas Impor Barang Kena Pajak Yang Dibebaskan Dari Pungutan Bea Masuk. Jakarta

[Permen] Peraturan Menteri. Peraturan Menteri ESDM No. 17 Tahun 2014 tentang Pembelian Tenaga Listrik Dari PLTP Dan Uap Panas Bumi Untuk PLTP Oleh PT Perusahaan Listrik Negara (Persero). Jakarta

[Permen] Peraturan Menteri. Peraturan Menteri ESDM No. 50 Tahun 2017 tentang Pemanfaatan Sumber Energi Terbarukan Untuk Penyediaan Tenaga Listrik. Jakarta

[Permen] Peraturan Menteri. Peraturan Menteri Keuangan No. 62/PMK.08/2017 tentang Pengelolaan Dana Pembiayaan Infrastruktur Sektor Panas Bumi Pada Perusahaan Perseroan (Persero) PT Sarana Multi Infrastruktur. Jakarta

Porter, M.E. (1985). Competitive Advantage: Creating and Sustaining Superior Performance. New York, US: The Free Pers

PT Sarana Multi Infrastruktur (Persero). (2015). SMI Insight 2015. Jakarta, ID: PT Sarana Multi Infrastruktur (Persero)

Rastogi, N., \& Trivedi, M.K. (2016). PESTLE technique - a tool to identify external risks in construction projects. International Research Journal of Engineering and Technology. $3(1), 384-388$

Ravanava, G., \& Charantimath, P. (2012). Strategic formulation using TOWS matrix - a case study. International Journal of Research and Development. 1(1), 87-90

Saaty, T.L. (1983). Desicion Making For Leaders: The Analytical Hierarchy Process for Desicion in Complex World. Pittsburgh, US: WS Publication

Saptadji, N.M. (2012). Diktat Kuliah TM 4261 Teknik Panasbumi. Bandung, ID: Penerbit ITB 
Satuan Kerja Khusus Pelaksana Kegiatan Usaha Hulu Minyak dan Gas Bumi. (2016). Laporan Tahunan 2016. Jakarta, ID: Satuan Kerja Khusus Pelaksana Kegiatan Usaha Hulu Minyak dan Gas Bumi

Setyaningsih, W. (2011). Potensi lapangan panas bumi Gedongsongo sebagai sumber energi alternatif dan penunjang perekonomian daerah. Jurnal Geografi. 8(1), 11-20

Sugiyono, A. (2012). Keekonomian Pengembangan PLTP Skala Kecil. Seminar Nasional Teknik Kimia Indonesia dan Musyawarah Nasional, 2012. Asosiasi Pendidikan Tinggi Teknik Kimia Indonesia. (33-39). Depok, ID: Departemen Teknik Kimia Universitas Indonesia

[UU] Undang Undang. Undang Undang Republik Indonesia No. 21 Tahun 2014 tentang Panas Bumi. Jakarta

[UU] Undang Undang. Undang Undang Republik Indonesia No. 27 Tahun 2003 tentang Panas Bumi. Jakarta

Wahyuningsih, R. (2005). Potensi dan wilayah kerja pertambangan panas bumi di Indonesia. Kolokium Hasil Lapangan - Inventarisasi Sumber Daya Mineral (DIM): 1-1-1-9

Walters, D., \& Rainbird, M. (2007). Cooperative innovation: a value chain approach. Journal of Enterprise Information Management. 20(5), 595-607

Weihrich, H. (1982). The TOWS matrix: a tool for situational analysis. Long Range Planning: 15(2), 54-66

Wheelen, T.L., \& Hunger, J.D. (2012). Concepts in Strategic Management and Business Policy. 13th Edition. New Jersey, US: Pearson Education, Inc 